\title{
The Cost of Checkable Deposits in the United States
}

\section{Kenneth C. Carraro and Daniel L. Thornton}

INANCLAL innovations and deregulation of the 1980s have changed significantly the types and composition of checkable deposit accounts offered by depository institutions. Both banks and thrift institutions now offer checking accounts that generate explicit interest retums as well as the more traditional ones that do not pay interest. These accounts. however, impose some implicit and explicit costs on their holders. This article reviews the costs and benefits associated with holding various forms of money, specifically the costs of holding various types of checking accounts. The results of recent surveys are used to illustrate the differing costs of these acounts.

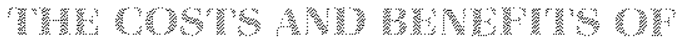

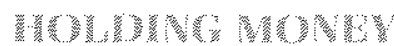

A primary function of money is to serve as a "medium of exchange, "that is, to facilitate the exchange of goods or services.' Most individuals receive their income, purchase the goods and services they desire and dispatch their debts with money? Indeed, eco-

Kentheth $C$. Carraro is an economist and Daniel $L$. Thornton is a senior economist at the Federal Reserve Bank of St. Louts. Rosemarie V. Mueller provided research assistance.

'We are silent on the exact nature of these services and their origin. For a discussion of these and other issues, see Brunner and Meltzer (1971). Alchian (1977) and White (1984).

"Of course, exchanges can be made "in kind" (barter). In fact, it is often argued that high marginal tax fates provide an incentive to avoid taxes by engaging directly in barter. Indeed, there has been an increasing awareness of this as, until recently, inflation had pushed a larger percentage of the population into higher marginal tax brackets. (1985 marked the first year that tax brackets were indexed for inflation.) Moreover, because curency transactions are less easily traced than transactions carried out by check, currency has a decided advantage over checks for those who wish to avoid laxes. nomic life would be significantly more complicated if money did not exist. Individuals would receive their income in the form of a bundle of goods and services that likely would differ from the one they would like to consume. They would be forced to use time and energy exchanging unwanted goods and services." Because the use of money facilitates such exchanges, thereby reducing the cost of exchange, it can be thought of as providing benefits to its holder. These are the so-called "non-pecuniary" benefits of holding money. In addition, if money is held in a form, like NOW accounts, on which interest is paid there may be some pecuniary benefits.

Since there are costs associated with holding money, an individual must balance the benefits of holding money against these costs. This problem is complicated because there are several types of money - cash tcoin and currencyl, traveler's cheoks and checkable deposits - that have differing advantages for different lypes of transactions. For example, traveler's checks generally are more useful than checking

Historically, the precise nature of these costs has been the subject of much discussion; see Brunner and Meltzer (1971), and Alchian (1977).

"This is a convenient and, for our purposes, useful characterization. Also, this idea forms the basis for some empirical definitions of money, e.g. Barnett's (†980) Divisia monetary aggregates. It is not, however, the only, nor perhaps even the preferred, basis for the existence of money. A significant number of economists argue that there are no direct benefits to holding money. Instead, they argue that the benefits of holding money are indirect; money essentially enables an individual to obtain a higher (more preferred) stream of consumption than could be obtained without its use. See Brunner and Meltzer (1971) and their cited references.

Specifically, individuals will add to their money balances until the marginal cost of holding the next doflar exceeds the marginal benefit of holding it. 
accounts when traveling out-of-state of abroad."

Different forms of money also have different costs associated with holding them. Furthermore, the financial innovations and deregulation in the 1980s have resulted in different types of checking accounts wilh different costs. Individuals must trade off these costs and benefits in deciding how much and what types of money to hold.

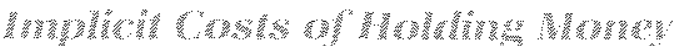

The costs associated with holding money can be divided into two broad categories: implicit and explicit. The implicit costs, called opportumity costs, primaxily are the income lost by holding money ather than assets that pay a higher interest rate: To illustrate, assume that you hold an average daily balance of $\$ 500$ per month in cash or non-interest-bearing demand deposits and that your next-best alternative is to deposit these funds into a savings account paying 5.5 percent per year." On average, the annual opportunity cost of holding $\$ 500$ in clemand deposits or cash is $\$ 27.50(\$ 500 \times .055)$

The opportunity cost varies with the size of the average daily balance held and the interest retum on available alternatives. For example, if the same $\$ 500$ had been held in a NOW account paying 5.25 percent. the opportunity cost would be only $\$ 1.251 \$ 500 \times$ $[.0550-.0525] \mid$ per year. Had the alternative, instead, been a money market asset paying an interest ate of 8 percent, the opportunity cost would be higher: $\$ 40$ $(\$ 500 \times .08)$ for demand deposits and cash and $\$ 13.75$ $(\$ 500 \times[.08-.0525])$ for NOW accounts." Thus, individuals have an incentive to economize on their money holdings when the interest return on one form of money is less than the rate paid on their next-best.

Eikewise, cash is generally more advantageous for small, everyday transactions, while checks are more useful for paying large bills, especially those involying out-of-cify of out-of-state fransactions. It is interesting to note that a significant portion of the population holds no checking accounts, but relies on money orders and the like to handle transactions for which cash is inconvenient. See Canner and Kurtz (1985).

${ }^{7}$ Costs will be associated with the lost use of funds if depository institutions require holding periods on checks drawn on out-of-city or out-of-state depository institutions.

8This rate was the legal maximum for commercial banks from January 1984 to January 1986.

${ }^{3}$ Consequently, if rates on these aiternatives vary directly with money market interest rates, while the rates paid on checking accourits do not, the amount held in these forms can be expected to vary inversely with market interest rates. non-money altemative and to choose the particular form of money that minimizes the cost, given their desire to make various transactions.

Depository institutions frequently specify that customers be charged an additional fee if their checking account balance falls below some specified level. These minimum balance requirements are most often imposed on checking accounts that pay explicit interest." All other things the same, the daily average balance held in an account increases by the difference between the minimum balance requirement and the minimum balance that would have been held if no requirement were imposed; the opportunity costs increase similarly. For example, suppose that an individual holds a daily average balance of $\$ 500$ but, because of the timing of his deposits and expenditures, the account balance never goes below $\$ 50$. If the depositing institution imposes a minimum balance requirement of $\$ 200$ and nothing etse changes, the daily average balance would increase by $\$ 150$ from $\$ 500$ to $\$ 650$. "Thus, minimum balance requirements increase the opportunity cost of holding these accounts to the extent that the required minimum balance exceeds what would have been held otherwise. Continuing with the previous example. the imposition of a $\$ 200$ minimum balance requirement on the demand deposit account increases the opportunity costs if the alternative is a 5.5 percent savings account from

\footnotetext{
${ }^{10}$ These requirements are imposed to cover the costs of servicing these accounts. Because funds may be drawn from these accounts at any time, depository institutions must maintain liquid assets to meet these deposit withdrawais. In general, their liquid assets earn a lower interest return than other portions of their assel portfolio such as loans. Consequently, depository institutions also face an interest opportunity cost for holding such liquid assets. Moreover, on a per dollar of deposit basis, explicit costs such as accounting, clerical services and wire transfers tend to be higher for accounts with more activity than for nontransaction accounts. In addition, there are explicit interest payments on interest-paying checking accounts.
}

The average daily level of these deposits constitutes a pool of funds that a depository institution can lend. The interest income from these loans is a major source of income for these institutions. Because minimum balance requirements increase the average daily funds available to a depository institution, they increase the institution's net revenue, all other things the same.

In addition, because these minimum balances are perpetually on deposit, there are no transactions and, hence, none of the usual clerical, wire transter and related costs associated with them.

FIn particular, this assumes that the individual does not alter his income and expenditure pattern. if the "cost" of doing so is less than the cost of holding larger average balances, however, the individual will respond by economizing on such deposits. As a resutt the average balance will increase by less than the difierence between the required and pre-required minimum balance. 


\section{$\$ 27.50$ to $\$ 35.75 . "$}

Depository institutions, however, usually reduce or waive their fees to depositors who meet minimum balance requirements. By holding a sufficiently large balance to avoid monthly fees, the cost of these accounts may be lower than other accounts not offering such fee-reducing balance levels. ${ }^{\text {it }}$

The opportunity costs associated with holding these deposits also varies with the method used to calculate the-interest paid on deposits. The most commonly used methods are; daily compounded interest, simple interest paid on monthly tor stafement period average balances and interest paid on monthly for statement period) minimum balances.

Finally, it should be noted that there is an implicit cost to holding money balances during periods of inflation. (During deflation there is a benefit.) Because some forms of money bear interest, while others do not the attractiveness of valious forms of money changes with the expected rate of intlation. Given the existing cost structures for these arcounts, this is true even if, as was the case for NOW accounts prior to January 1986, there is a legal maximum interest rate on these deposits that does not increase with inflation.

\section{Wha}

In addition to the implicit costs of holding checkable deposits, there are explicit costs if money is held in specific types of checkable deposits." These costs fall into three categories: flat service fees fusually

1alt should be noted, however, that checkable deposits have a reserve requirement (currently 12 percert of the account balance) that must be held in a non-interest-bearing form. Because this "reserve tax" is higher for checkable deposits than for savings deposits, depository insitutions have an incentive not to impose too high a minimum balance requirement. If unds are simply switched from savings accounts with lower or no reserve tax to checkable deposits, the total nes revenue for the institution could decline. Competition among institutions is another constraint on raising minimum balance requirements. It is possible that an increased balance requirement at one institution would cause its lotal deposits to decine, as its customers shift deposits to other institutions.

The interest rate on alternative assets would have to be high for it not to pay to meet the mirimum balance requirement necessary to wave all fees. For example, using numbers from the survey data reported below, assume annal service fees of $\$ 74.76$ on a NOW account bearing 5.25 percent. Assume that an individual normally holds a minimum balance of $\$ 100$, but that the institution requines a minimum balance of $\$ 1,047$ to wave all service fees. The interest rate that the individual would have to earn on altemalive assets to make it worthwhile not to hoid the minimum balance would have to be greater than 13.14 percent.

Because checkable deposits may have costs that do not exis for cash, the costs of holding cash may be lower than the costs of interest-paving demand deposits. White this is true, it should be remembered that such deposits may offer more services and grealer security than cash. monthly!, per-check service fees and check-printing fees. Flat service fees are charged directly on each account and are independent of the number of checks written. Per check fees are based solely on the number of checks written. Of course, depository insitutions may impose a combination of such fees. Indeed, thene is a wide variety of such plans, often offered by the same depository institution. For example, the flat fee per account may vay with the monthy average $1 \mathrm{o}^{\circ}$ minimum) balance in the account; the flat fee is usually lower, the larger the checking account balance held. Likewise, depository instiutions may vary the per-check fee with the average for minimum balance held. Finally, some institutions provide checks free of charge to depositors; others charge for them.

Given both the range of accounts available and the variation in the charges on these accounts, it can be quite difficult for an individual to choose the account with the lowest net cost. Unfortunately, this article cannot provide specific advice on such choices; the next section, however, presents recent U.S. survey information to illustrate these costs for representative depositors.

\section{W

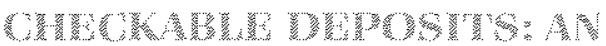

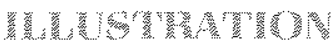

This section illustrates the costs of holding fou' foms of checkable accounts. Since costs vary according to numerous characteristics, including the average balance, three representative depositors having low, medium and high monthly average balances are used.

A balance of $\$ 500$ is used as the baseline balance for the "middle" individual; two other representative in" dividuals are assumed to have balances of $\$ 300$ and $\$ 1,000$, respectively." The minimum balances held by

\footnotetext{
15The 1983 Survey of Consumer Finances (Avery and Elliehausen, forthcoming) found that the median balance in the primary checking account for families was $\$ 500$, the median balance for families with incomes in the lowest 10 percent of those sampled was $\$ 300$, white the median balance for families with incomes in the highest 10 percent was $\$ 1,000$. The median account balance data from the Survey of Consumer Finances differs sharply from average balance data compled by the $\mathrm{ABA}$ on a national basis. The $\mathrm{ABA}$ average account balance for tiered checking accounts in 1984 ranged from $\$ \$, 000$ to $\$ 1,700$ depending on bank size. The average NOW account balance ranged from $\$ 4,500$ to $\$ 6,600$ for the $A B A$ survey. The reason for the difference between the $A B A$ data and the Survey of Consumer Finances is the use of average vs. median account balances. Data using averages have the disadvantage of being skewed by extremely large or small accounts. The use of median data avoids this problem by selecting the middle data point in a series so that hat the values are less than the median while the other half exceed the median.
} 
these thee individuals are assumed to be one fouth of their avemge monthly balances. These balance characteristics plus data on the number of checks whiten per account are presented in table $1 .^{26}$

The characteristics of the fow checkable accounts are shown in table 2 . These chatacteristies are derived from survey data collected by Sheshunoff and Company, Inc. Isee the appendix for a description of the datal. The first three accounts - no-fills, basic, and tiered demand deposits - pay no explicit interest, while the fourth, a NOW account, is assumed to pay 5.25 percent interest.

No-frills checking accounts are designed to provide low-cost checking to depositors whose monthy balances are low and who wite relatively fow checks. Basic demand deposit accounts have a flat monthly fee that is waved when the account hatance exceeds some average or minimum level. Tiered demand de posit accounts have monthly fees that are calculated on the account's average on minimum balance. Typ:cally, the higher the balance, the lower the monlhy lee - up to a point at which, with suffeiently high balances, all fees are waived

Now accomnts are checkable accounts that pay explicit interest. Until January 1,1986 , banks were legally restricted to paving a maximum interest rate of 5.25 pereent on NoW aceounts whose minimum monthly balance fell below $\$ 1.000 .{ }^{2}$ As of January 1 , 1986, all interest rate restrictions were removed fom Now accounts. Many Now accounts, hike tiered de mand deposits, have fees that are levied according to the account's bakance.

Table 2 presents data on a number of fee items. The monhly maintenance tee is the average of the maxi mum fee that the sureyed banks charged on these: accounts. These fees are charged regaldless of the minimum balance mantained for the nowills accounts. For basic demand deposits, these fees were waved if the minimum balance in the account was at least $\$ 452$. For both tiered demand deposits and NoW accounts, the maximum monthly fee was reduced from the amounts shown by holding balances in $\mathrm{ex}$ -

\footnotetext{
:These data are drawn from Avery and others (1986). This work, which is based on the Survey of Currency and Transaction Account Usage conducted in 1984, focuses on the household sector of the economy. The survey obtained 1,946 completed telephone interviews from a randomly selected sample of 2,500 families in the United Stales.

${ }^{17}$ For a discussion of the issues surrounding Regulation $Q$ see Gilbert (1986).
}

Table 1

\section{Comparison of Checking Accounts by Representative Individuals}

\begin{tabular}{|c|c|c|c|}
\hline & Individual A & Individual $\mathbf{B}$ & Individual $\mathrm{C}$ \\
\hline $\begin{array}{l}\text { Average monthly } \\
\text { balance }\end{array}$ & $\$ 300$ & $\$ 500$ & $\$ 1,000$ \\
\hline $\begin{array}{l}\text { Minimum monthly } \\
\text { balance }\end{array}$ & $\$ 75$ & $\$ 125$ & $\$ 250$ \\
\hline $\begin{array}{l}\text { Checks per } \\
\text { month }\end{array}$ & $\therefore 10$ & 16 & 24 \\
\hline
\end{tabular}

cess of $\$ 236$ and $\$ 943$, respectively, and waived for minimum balances of $\$ 491$ and $\$ 1,047$, apectively.

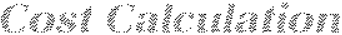

The costs for thee representative individuals are calculated from the ata shown in table 2. Details of these calculations are presented in the insert on the opposite page. The calculations assume that all hank impose these charges where relevant.

A number of qualifications are appropriate at this point. For example, while all banks are assumed to impose these fees, sumey ctata indicate that $6.3 \mathrm{per}-$ cent of all responding banks offered the basic demand deposit account without fees of mirimum balance requirements. Furthermore, as noted. lhe maximum monthly fees may be reduced for sone accounts by holding balances that are smaller than those that are indicated to wave all fees. Also, thete is evidence fiom the American Bankers Association ABA surey and the 1983 Survey of Cumency and Transactions Account Usage (see Avery and others, 1986) that many individaals hold deposit balances far in excess of those required to wave all fees. nndeed, 59 percent of the families responding to the 1983 suvey of Cumency and Transactions Account Usage indicated that they usually do not pay a fee on the household's main checking account. Consequently, these calculations

\footnotetext{
18This is due primarily to holding account balances so large that interest earnings offset the accoun fees: however. this also represents responses from families who have selected non-fee accounts. The Sheshunof data indicate that over 77 percent of the banks surveyed offered tree checking accounts to senior citizens, 30 percent offered free checking to students and 19 percent used depositors' balances in savings accounts to offset checking account fees.
} 
Table 2

Key Characteristics of Four Checkable Accounts

\begin{tabular}{|c|c|c|c|c|}
\hline & No-Frills & $\begin{array}{l}\text { Basic } \\
\text { demand } \\
\text { deposits }\end{array}$ & $\begin{array}{l}\text { Tiered } \\
\text { demand } \\
\text { deposits }\end{array}$ & NOW \\
\hline Monthy mantenance fee & $\$ 1.48$ & $\$ 315$ & $\$ 5.45^{1}$ & $\$ 6.23$ \\
\hline $\begin{array}{l}\text { Highest batance to which } \\
\text { maximum fee applies }\end{array}$ & NA & $N A$ & $\$ 236$ & $\$ 943$ \\
\hline $\begin{array}{l}\text { Mnimum balance needed } \\
\text { to waive monthly fee }\end{array}$ & NA & $\$ 452$ & $\$ 491$ & $\$ 1047$ \\
\hline Number of free checks monthly & 15 & 19 & 24 & 25 \\
\hline Percheck fee after limit & $\$ 0.23$ & $\$ 0,16$ & $\$ 016$ & $\$ 0 \$ 8$ \\
\hline
\end{tabular}

These fees represent the maximum monthly fee that applies to balances below $\$ 236$ in the case of tiered demand deposits and below $\$ 943$ for NOW accounts. The Sheshunof data provide only the maximum fee, while the ABA data provide the range of fees that applies to minimum account balances from $\$ 0$ to the balance level required tor fees to be waived for mimimum account balances that fall between $\$ 236$ and $\$ 491$ for tiered accounts and between $\$ 943$ and $\$ 1,047$ for Now accounts the fee is esthated using the ABA data to adiust the fee data from Sheshunoff.

SOURCE Derived from Sheshunoff Survey Data

are illustrative; they need not reflect any particular individual's explicit costs of holding various types of checking accounts.

Table 3 presents the calculated monthy explicit cost of the four tansaction accounts. Although Now accounts have the highest maximum monthly service charge, the earned interest income an make thei monthly before-tax net cost quite low, especially for an individual with large minimum and/or avenage balances. Indeed, the monthy before-tax net cost would be negative il average balances were grealer than $\$ 1,425$, regardless of how low the minimum balance was. Since survey data indicate that the average balance in these accounts is in the $\$ 5,000-\$ 6,000$ range, it would not be suprising to find that many Now account holders have negative monthly net costs.

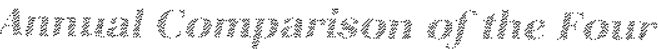

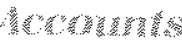

Table 4 summarizes the results of tabte 3 on an annual basis. The cost of purchasing checks is in cluded in the annual cost based on the average number of checks written from table 1 . A 1984 study analvzing retail banking fees found the average charge for 200 checks to be $\$ 6.25 .^{\text {: }}$

${ }^{10}$ Trans Data Corporation (1984). The ABA survey found the charge for 200 checks to vary from $\$ 5.18$ to $\$ 6.51$.

\section{The Cost Calculation Formula}

The followng simple equation is first used to calculate he monthy before 1 ax costs Tax molica tions are discussed in a later section then the net oosts, which indude the cost of buying checks, ale compared on an anmual basis for all four acoumb.

Monthly Net Cost - Intewesi Eaned on Deposits mmus Monthly Mamtenance Fee nenus Per Chedk Fees,

canbe nestated as

Net Cost $-\frac{1 \mathrm{X}}{12} \mathrm{~N}-\mathrm{pN}-1$,

where

1 - miteresl nate pard on deposits

$\mathrm{X}=$ average monthly balanice

$\mathrm{M}$ - monthly foe, a funetion of minimum monthly balances:

$\mathrm{p}$ - petcheek fee lapplies only when $\mathrm{N}>\mathrm{L}$

$\mathrm{N}=$ number of ehed ch whiten per month

$L \_$limit of free checks pen month 


\section{Table 3}

\section{Net Costs of Alternative Checking Accounts for Representative Individuals}

\begin{tabular}{|c|c|c|c|c|}
\hline & $\begin{array}{l}\text { No-frils } \\
\text { DD }\end{array}$ & $\begin{array}{l}\text { Basic } \\
\text { Do }\end{array}$ & $\begin{array}{l}\text { Trered } \\
\mathrm{DD}\end{array}$ & $\begin{array}{l}\text { NoW } \\
\text { accoun }\end{array}$ \\
\hline \multicolumn{5}{|c|}{ Individual $A$} \\
\hline Interest earned & 0 & 0 & 0 & $\$ 131$ \\
\hline Monthy tee & $\$ 148$ & $\$ 315$ & $\$ 545$ & $\$ 623$ \\
\hline Check fee & 0 & 0 & 0 & 0 \\
\hline Monthy net cost & $\$ 148$ & $\$ 3,5$ & $\$ 545$ & $\$ 492$ \\
\hline \multicolumn{5}{|c|}{ ndividial $\mathrm{B}$} \\
\hline nterest earned & 0 & 0 & 0 & $\$ 219$ \\
\hline Monthy lees & $\$ 148$ & $\$ 315$ & 8545 & $\$ 6.23$ \\
\hline Check tee & $\$ 023$ & 0 & 0 & 0 \\
\hline Nonthy notcost & $\$ 171$ & $\$ 315$ & $\$ 5,45$ & $\$ 404$ \\
\hline \multicolumn{5}{|c|}{ Individuale } \\
\hline Interest eaned & 0 & 0 & 0 & $\$ 438$ \\
\hline Monthy tee & $\$ 148$ & $\$ 3,15$ & 8518 & $\$ 6,23$ \\
\hline Check fee & $\$ 207$ & 5080 & 0 & 0 \\
\hline Monhly netoost & $\$ 355$ & $\$ 395$ & $\$ 5,8$ & 8185 \\
\hline
\end{tabular}

Individual C has a nihinum balance of $\$ 250$ but the highest tee is assessed for balances up to $\$ 236$, the nonthy fee ol $\$ 5.45$ was recuced by 5 percent $10 \$ 5,18$, The 5 percent reduction is the average amount by which the nonthy fee was reduced from is naximum according to $A B A$ data.

Table 4 indicates that individuals $A$ and $B$ would opt for the no-frills account at anmual costs of $\$ 21.51$ and $\$ 26.52$, respectively, while individual $C$ would clearly prefer the NOW account at an anmual cost of $\$ 31.26$.

While the data in table 4 do not necessarily represent the cost of various types of deposits for a given individual, there is a clear relationship between the average daily balance and the cost of various types of accounts. As a general rule, the higher the average daily balance, the more likely it is that NOW accounts will be the least costly form of checkable deposits. Indeed, for very large average and/or minimum balances, NOW accounts likely will be the most costeffective checking account among all the altematives. Likewise, no-frils demand deposits likely will be the least costly alternative for individuals who hold rela-

For example, the net annual cost of $\$ 31,26$ for individual $C$ includes $\$ 52.50$ of interest eamed $(\$ 1,000 \times .0525)$ and $\$ 83.76$ of fees. The fees include $\$ 74.76$ of monthly maintenance tees $(12 \times \$ 6.23)$ and $\$ 9.00$ in charges for checks $(24 \times 12 \times \$ 6.25 / 200)$

\section{Table 4}

\section{Annual Cost of Four Checkable Deposit Accounts for Representative Individuals (including the cost of checks)}

\begin{tabular}{|c|c|c|c|}
\hline & Individual $\mathrm{A}$ & Indivicual $\mathrm{B}$ & Individual $\mathrm{C}$ \\
\hline $\begin{array}{l}\text { Uofrils } \\
\text { acolnt }\end{array}$ & $\$ 2151$ & $\$ 2652$ & $\$ 51600$ \\
\hline basic demand & $84 / 55$ & $\$ 4380$ & $\$ 56,40$ \\
\hline Tleseddenand & 59, & 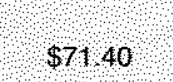 & क्रि \\
\hline nowaseount's & $\$ 6276$ & $\$ 5451$ & $\$ 3126$ \\
\hline
\end{tabular}

tively small balances. ${ }^{24}$ Similar results were arived at using Eighth District data in place of national data (see opposite pagel. While our calculations do not illustrate a situation in which either basic or tiered demand deposits are preferred, there clearly are combinations of average and minimum balances and explicit fees for which these accounts will be the least costly alternative.

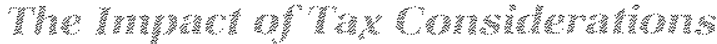

It is also important to consider the tax liabilities arising from interest on deposits. Tax effects are importan because interest income on bank deposits is taxed as ordinary income, without consideration of monthy service fees. For example, in one year, individual Ceamed 552.50 in interest on the NOW account and paid $\$ 83.76$ in account fees for a net annual cost of \$31.26. In that year, individual $C$ would be faxed on the $\$ 52.56$ of interest income rather than paying no laxes on the $\$ 31.26$ of net expense. If this depositor were in the 30 percent marginal tax bracket, the account would result in an after-tax cost of $\$ 47.01,1 \$ 31.26+.3$ \$ $\$ 52.501$ ), instead of the before-tax cost of only $\$ 31,26$. If this depositor were in the 50 percent tax bracket, the

21indeed, survey data indicate that the percentage of families holding only regular non"interest paying demand deposits dectines substartially with family income, while the proportion with only NOW accounts increases. We woutd like to thank Mobert Avery for providing us with these dala. 


\section{The Cost of Checkable Deposits in the Eighth Federal Reserve District}

This insent compares the fee structure on checka ble accounts in the Eighth District with that of the nation It also investigates whethet he three representat we individuals would have ohosen different checkable accounts had they been located in the Distriet The Eighth Federal Resenve District neludes all of Arkansas and parts of Ulino is, Indiand aceounts using the Disthet data it hadicates that although the absolute costs in the District ate dif ferent than the national costs, the selection of the lowest cost account for each of the three haviduals is unchanged.

Eighth Bistrue data hom the Quarterly Sunvey of Number of selected Deposit Accounts and the pe

Table A

\section{U.S. and Eighth District Comparison}

\begin{aligned} \hline \\ \hline\end{aligned}

SOURCE Sheshunot $(1986)$

Kentucly, Mississippl, Missouri and Tennessee. As of December 31,1985 , there were neaty 1,400 banks in the District The primary data source for this article, Sheshumoff (1986), provides a state-by-state breakdown of most fees for some of the major checkable accounts, An Eighth District tee structure is constructed by combining data from al seven states that are part of the Distuct the num ber of observations for the District data ranged from 74 to 325

In the cases in which regional data wee not available, national data were substituted Fable $A$ compares the natonal and District data where such comparisons are possible It shows that the District data corespond closely with the national data. There are no consistent differences; however the national fees are sometimes higher than District fees, while at other times the opposite is true.

Table $B$ repleates table 4 of the main lext It provides the annual cost of the four checkable port of Transaction Acoounts indicate an average NOW account balance of $\$ 6,554$ in the first quate: of 1986 These District findings comespond closely to the $\mathrm{ABA}$ national suvey results which indicate an avenge NOW account balance of $\$ 4,500$ to $\$ 6,600$ depending on the size of the bank.

Table B

Annual Cost of Four Checkable Deposit Accounts in the Eighth District

\begin{tabular}{|c|c|c|c|}
\hline & Individual $\mathbf{A}$ & Individual $B$ & Individual $\mathrm{C}$ \\
\hline $\begin{array}{l}\text { No-frils } \\
\text { account }\end{array}$ & $\$ 21.27$ & $\$ 27.60$ & $\$ 52.68$ \\
\hline $\begin{array}{l}\text { Basic demand } \\
\text { deposit account }\end{array}$ & 44.19 & 46.44 & 60.84 \\
\hline $\begin{array}{l}\text { Tiered demand } \\
\text { deposit account }\end{array}$ & 66.27 & 68.52 & 77.64 \\
\hline NOW account & 63.48 & 55.23 & 31.98 \\
\hline
\end{tabular}


after-tax cost of the account would be $\$ 57.511 \$ 31.26+$ $.51 \$ 52.501$. In this case, the NOW account would no longer be the lowest-cost checking altemative for the high balance depositor. Instead, the no-frills account would be the least costly form. As a general rule, the higher the marginal tax rate, the higher the average and/or minimum balances required to make NOW accounts the least costly altemative.

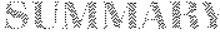

This article reviews the costs and benefits of holding money and outlines the calculations involved in determining the amoun and type of money balances one would want to hold. In addition, the explicit costs of holding fou types of checking accounts are calculated for thee representative depositors. The purpose of this discussion is lo provide a better understanding of the costs and benetits of holding money and to make it easier for consumers to compare annual costs on alternative checking accounts.

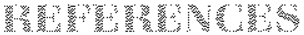

Alchian, Armen A. "Why Money?" Journal of Money, Credit and Banking (February 1977), pp. 133-40.

American Bankers Association. 1984 Retail Deposit Services Report (Washington: ABA, 1985).

Avery, Robert B., Gregory E. Ethehassen, Arthur B. Kennickell and Paul A. Spindt. "The Use of Cash and Transaction Accounts by
American Families," Federal Reserve Bulletin (Februafy 1986), pp. 87-108.

Avery, Robet B., and Gregory E. Eltiehausen. "1983 Survey of Consumer Finances," (Board of Governors of the Federal Reserve System, forthcoming).

Barnett, Wiliam A. "Economic Monetary Aggregates: An Application of Index Number and Aggregation Theory," Journal of Econometrics (September 1980), pp. 11-48

Brewer, Eljah III. The Impact of Deregulation on the True Cost of Savings Deposits: Evidence from Minois and Wisconsin Savings and Loan Associations, Federal Reserve Bank of Chicago, Staff Memoranda 85-4 (August 1985).

Brunner, Karl, and Allan H. Meltzer. "The Uses of Money: Money in the Theory of an Exchange Economy," American Economic Review (December 1971), pp. 784-805.

Calem, Pats. "The New Bank Deposit Markets: Goodbye to Regulation Q," Federal Reserve Bank of Philadelphia Business Review (November, 1985), pp. 19-29.

Canner, Giem B., and Roben D. Kurz. Service Charges As a Source of Bank income and Their Impact on Consumers, Board of Governors of the Federal Reserve System, Staff Study \#145 (August 1985).

Fama, Eugene F. "What's Different About Banks?" Joumat of Monetary Economics (January 1985), pp. 29-39.

Gibert, R. Alton. "Requiem for Regulation Q: What it Did and Why it Passed Away," this Review (February 1986), pp. 22-37.

Sheshunoff \& Company, Inc. Pricing Bank Services and Loans 1986.

Trans Data Corporation, A Comparative Analysis of Retail Banking Fees (1984).

White, Lawrence $H$. "Competitive Payments Systems and the Unit of Account," American Economic Review (September 1984), pp. 699-712.

\section{APPENDIX The Data Sources}

The primary data source for the explicit costs of these checkable deposit accounts is the most recent annual survey published by Sheshunoff and $\mathrm{Co}$., Inc., entitled "Pricing Bank Services and Loans 1986." $\mathrm{Na}$ tionally, over 1,300 commercial banks responded to a detailed survey which asked banks to list the charges associated with the "checking account used by most of your customers" for each of many different accounts. For example, if a bank offers three distinet NoW accounts to depositors, its survey responses provicle data only for the most widely used of the three.

The data requested include minimum balance requirements, service charges, per-check charges and a variety of other information related to the costs and returns of holding checkable deposits. The Sheshunoff data provide weighted average rather than median values. It is assumed that all charges and fees assessed are based on the minimum balance held because over 85 percent of respondent banks indicate they calculate these charges on the basis of minimum, rather than average, balances.

Another data source is the "1984 Retail Deposit Services Report" by the American Bankers Association (ABA). The ABA sampled 1,735 banks and published data from 377 respondents broken down by asset size of the banks and solicited account information similar to the Sheshunoff survey. In most cases, the Sheshunoff data are used in the analysis. 


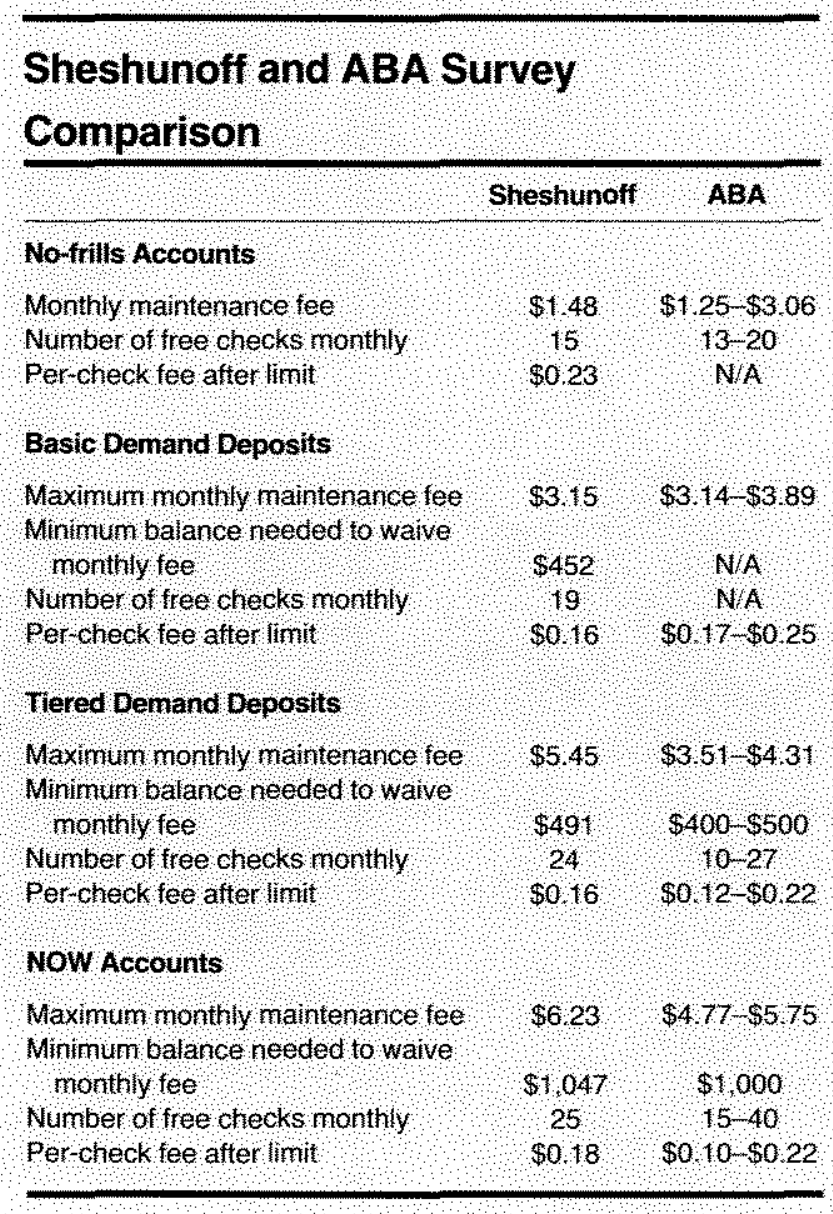

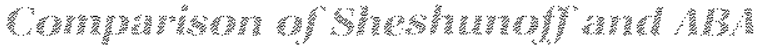

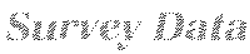

Both the Sheshunoff and ABA surveys collect data on the four checkable accounts analyzed in this article although slightly different terminology is used to describe some of the accounts. Both surveys refer to nofrills and NOW accounts but use different terms in reference to basic and tiered demand deposit accounts. The Sheshunoff survey uses the term "metered" checking account and the $A B A$ uses "special" checking account to refer to the basic demand deposit account fo: which a fee is assessed without regard to the account's balance. Tiered demand deposit accounts, for which fees are assessed as a function of the account's balance, are caled " $3-2-1$ " accounts by the Sheshunoff study and "regular" checking by the $A B A$ study.

While the account definitions and the manner of displaying survey results are not identical for the two studies, basic data comparisons can be made. Though Sheshunoff data are reported by the deposit size of the bank, an average for all banks is provided as well. The ABA data do not provide averages for all banks and, therefore, a range of fees and balance levels are presented in the following table. The ABA survey was completed in 1984, while the Sheshumof study was done in 1985. The following comparisons in table $A$ show that the two studies arrive at similar account fee structures. 